\title{
Changes in Farms Economic Sustainability: The Picture of Polish Farms in the Last Decade
}

\author{
Wioletta Wrzaszcz ${ }^{1}$
}

\begin{abstract}
The European Union took a course on sustainable agriculture and rural development. This direction of agricultural policy has been implemented for many years. With the passage of time is increasing need to determine the actual effects in terms of sustainability. Agriculture sustainability takes into account three basic aspects, i.e. economic, environmental and social. In the case of farms, the economic sustainability is particularly important because it is associated with the basic economic objective of farmers and motive of their economic activity. Sustainability of agriculture and farms is the subject of increasing interests of society and researchers. In recent years, various research institutions take attempts to measure sustainability, including economic issues, but there was no uniform approach to this research subject. The aim of the paper is to present the changes that have taken place in agriculture economic sustainability in Poland. Using public statistic, 2005 and 2016 data of Central Statistical Office, the direction in which tends the Polish agriculture was indicated. There was used a set of useful economic indicators that can be applied in other EU countries. Farms ' economic sustainability was assessed on the basis of land and labour productivity and profitability, households income sources and farms market activity. The analysis concerns all individual agricultural holdings with at least 1 ha of agricultural land.
\end{abstract}

Keywords: economic sustainability, farms`economic sustainability, agriculture, Central Statistical Office data, Poland

\section{Introduction}

For many years, the idea of sustainable development has been dominating political and social discussions in both developing and developed countries. The sustainable development is also one of the major study subjects undertaken by scientists in various parts of the world. A broad interest in the sustainable development results from a need to look for solutions that take into account not only economic, but also social and environmental considerations.

The popularisation of the idea of sustainable development results in the proliferation of various concepts matching this direction of development. Despite such a great interest in this issue, the concept of sustainable development still is understood and defined in different ways (Zegar, 2012; Toczyński, Wrzaszcz, Zegar, 2013). Undeniably, the theoretical basis for this concept is to take into account the needs of the current and the future generation (World Commission on Environment and Development, 1987). This concept takes into account both different sectors of the economy and different dimensions, namely, environmental, economic and social.

Agriculture is one of the main sectors of the national economy. The way in which farms are organised largely determines the sustainability of the entire agricultural sector. In the

\footnotetext{
1 Institute of Agricultural and Food Economics - National Research Institute, General Economic Department, 00-002 Warsaw, Świętokrzyska 20, Poland
} 
case of farms, the individual dimensions of sustainability have a different meaning than in the case of the entire agricultural sector (Zegar, Wrzaszcz, 2017). In the case of an economic unit, particular importance is attributed to the economic sustainability, and more precisely, to the level of economic results which determine the life of the farmer's family and the functioning of the farm in the market.

Since mid-2004, Poland has been a member of the EU. The accession resulted in the launch of many programmes to support the economic development, including the development of agriculture. The orientation of the agricultural policy towards the sustainable development of agriculture and rural areas has been associated with implementing a series of measures and instruments facilitating the transformation of farms. In the case of Poland, these instruments have been mainly implemented since 2005. These instruments, on the one hand, were to promote the reorganisation of farms in the environmental direction and, on the other, to improve their economic situation, which largely determines their innovation and competitiveness (Ministry of Agriculture and Rural Development, 2018). Now, after several years from the Polish accession to the European Union, there is a need to identify the current economic effects of farms, as these results determine the level and scope of the sustainability of farms. The aim of the paper is to present the changes that have taken place in agriculture economic sustainability in Poland in the last decade, using public statistic data.

\section{How to Measure Agriculture Sustainability?}

Measuring the sustainability of agriculture is very complex, that was underlined in numerous scientific studies ${ }^{1}$. The common approach to this issue is associated with using certain indicators relating to three aspects of sustainability, namely: environmental, economic and social (Woś, Zegar, 2002; van Huylenbroeck, Durand (eds.), 2003; Pretty, 2008; The Royal Society, 2009). The indicators measuring the sustainable development in general, formulated by international organisations are also useful in measuring the sustainable development of agriculture, however, they usually require adaptation to the specific nature of this economy sector (OECD, 1999; CEC, 2000; OECD, 2001; EC, 2006; EC, 2008). Attempts in this field using a variety of approaches have not resulted in a generally accepted set of indicators to measure sustainability.

The difficulties in measuring the sustainability of agriculture have many causes. First of all, the term of sustainable agriculture is not clearly defined. The measurement is hampered by multifunctionality of agriculture, a huge diversity of farms, different directions of the same effects on the environment and the production and economic performance, diverse aspirations of farmers and others. There are also attempts to formulate a synthetic indicator of agricultural sustainability (Jankowiak, Bieńkowski, 2007; Majewski, 2008; Wrzaszcz, 2014). Commonly, the most attention in research is paid to environmental order, which was the base for the idea of sustainable development (more precisely, a dramatic violation of this order). The situation with regard to the measurement of economic and social orders is less clear. In the case of economic order,

1 See e.g. (vanLoon et al. 2005; Wilk 2005; Faber 2007; Jankowiak, Bieńkowski 2007; Majewski 2008; Toczyński et al., 2009; Sadowski, 2012; Zegar, 2012; Wrzaszcz, 2014). 
the most important indicators are those related to food security, the ability to create income for the purposes of productive investment and income of the population engaged in agricultural activity, and especially people living mainly from farming (Wrzaszcz, Zegar, 2014).

A separate, although very important, issue is the method to measure the sustainability of agriculture $^{2}$ that would enable an international application. In connection with the use of various definitions of sustainability, various data (from various sources and studies), as well as various study methods (including different indicator and synthetic methods), the results obtained for the sustainability of agriculture in a specific country are usually not useful for making international comparisons. The problem is that both researchers and international organisations often do not use international data collected in a uniform manner. This problem justifies a need to adapt the theoretical considerations (widely discussed in the literature) to the scope of available, unified national data in order to develop a useful method to be used when making an international comparison of the sustainability of agriculture, including farms, also in the economic dimension. The comparability of data is provided by EUROSTAT, although the scope of this data does not make it possible to study the sustainability of agriculture (farms) to the full extent, hence, it does not exhaust the scientific theoretical considerations.

\section{Research Method}

Public statistic of Central Statistical Office - 2005 and 2016 Farm Structure Survey (FSS) data were used. These date were collected on the basis of uniform methodology that allowed to investigate the direction in which tends Polish agriculture with regard to economic sustainability. FSS research are carried out in individual EU countries, that results are finally aggregated in EUROSTAT databases. The proposed use of data from FSS to measure economic sustainability of farms and agriculture can be applied to other countries to conduct comparative analyses between them, taking into account the different requirements of sustainability.

The analysis concerns all individual agricultural holdings with at least 1 ha of agricultural land maintained in good agricultural and environmental condition. The research also eliminated farms with legal personality ${ }^{3}$, due to their different specificity of organization, functioning and production potential in comparison to individual ones. The farms ' characteristics concerned economic and production potential used in the research were the following: area of agricultural land (ha), labour input (expressed in Annual Work Units - AWU4), animal population (Livestock Units - LU5), the value of standard output

\footnotetext{
2 The sustainability of agriculture is determined by the sustainability of farms, although the latter does not exhaust the first.

3 In Poland - excluding individual holdings - there were also 4.1 thousand farms owned by legal persons (2016), using 1,249 thousand ha of agricultural land (8.6\% of agricultural land in total) and producing standard output with a value of EUR 2,314 million (9.5\% of total value).

$41 \mathrm{AWU}$ is equivalent to full-time, that is 2,120 hours of work a year.

$51 \mathrm{LU}$ is a conventional unit of farm animals with a mass of $500 \mathrm{~kg}$. See tables of conversion coefficient for livestock from physical units to livestock units (Toczyński et al., 2013).
} 
(EUR thousand) ${ }^{6}$ and standard gross margin (European Size Units - ESU) 7 .

FSS data allowed for setting the indicator values of agriculture economic sustainability based on farms' sustainability. There was used a set of useful economic indicators that can be applied in other EU countries. Farms` economic sustainability was assessed on the basis of land and labour productivity and profitability, households income sources and farms market activity. Based on FSS data, there were determined values of several complementary indicators that can be used in assessing the economic sustainability of farms. These indicators included the following:

- the value of the standard output per hectare of agricultural land (EUR thousand/ha) indicates the level of land standard productivity. It is an important indicator of agricultural production volume in the context of food security.

- value of the standard gross margin per full-time employee (ESU/AWU) - can be used as a measure of the level of potential labour charges and the assessment of economic efficiency of labour. As a result, this indicator informs about potential investment and consumption funds of households and farms.

- the share of farms with more than $50 \%$ of commercial production in direct sales, i.e. at the local markets, in own stores, under sale to neighbours (the so-called local market agricultural holdings) - entities operating on the local market provide benefits to local communities, which are reflected not only in more convenient ways to buy goods, often for a lower price as compared with products produce in longer food chains, but also contribute to the development of neighbourly ties and sustaining of rural areas vitality.

- the share of farms selling at least $50 \%$ of agricultural production on the market (the socalled market agricultural holdings) - market activity of farms indicates the scale of farms linkages with market, including the local market.

- share of farms with majority household's income from agricultural activity (the socalled farmers' agricultural holdings ${ }^{8}$ ) - indicates the percentage of farms oriented on active functioning on the market. The opposite group are subsistence farms where at

\footnotetext{
${ }^{6}$ Standard output is the mean of 5 years of the value of production corresponding to the average situation in the region. Total standard production of farms is the sum of the values obtained for each agricultural activity on the farm by multiplying the coefficients of the standard output for a given activity and the number of hectares or number of animals; see (Goraj et al., 2012). It is an economic category that allows for comparing the volume of production, while offsetting the impact of price fluctuations in regional and temporal terms. There were used 2013 standard output indicators (based on the average values for the period 2011-2015).

${ }^{7}$ Sum of standard gross margins (SGM) - the difference between output and specific (direct) costs of all activities occurring on the farm - indicates the economic size of the farm, otherwise the productive potential of the farm. 1 ESU is equivalent to EUR 1,200. The standard gross margin is the average gross margin by region. Standard gross margin on a particular crop or animal is a standard (average of three years in a particular region) value of production obtained from one hectare or from one animal less the standard direct costs necessary to produce. There were used 2004 standard gross margin indicators - the last SGM calculated indicators, used in Farm Accountancy Data Network (FADN). In subsequent years, there was used FADN farms`typology based on the coefficients of standard output.

8 The predominant source of farm's income indicates its socio-economic type. This classification distinguishes the following groups: farmers' holdings - with majority income from agricultural activities, employees' households - with majority income from employment, entrepreneurs' households - with majority income from non-agricultural activities, pensioners' households - with majority income from pension, other - with majority income from other sources. Data collected under the FSS 2005 and 2016 allow for the classification of farms according to the predominant source of income of a farming family, but they do not include the absolute level of income, among other thing agricultural income.
} 
least half of the agricultural production is used for own household's needs. The relationship between these groups of farms determines the scale of agricultural linkages of economic entities with the market, thus the scale of production, their market orientation and potential to ensure an adequate volume of agricultural production.

\section{Research Results}

\subsection{Farms`Production and Economic Potential Changes}

Agriculture in Poland has changed significantly over the last several years. These changes concerned mainly the number of farms, their potential and production profile as well as their economic potential (Table 1). In 2016, in agriculture there were 1.4 million individual farms with an area starting from 1 ha of agricultural land in good agricultural condition. When compared to 2005, the number of those farms decreased by almost $1 / 5$. These are significant changes indicating the withdrawal of many farmers from this economic activity. The reasons for this can be seen, on the one hand, in the fact that agricultural producers choose the state pension (by virtue of reaching the required age) and early retirement (for farmers of working age) and, on the other, in taking activities, including other economic activities, not related to agriculture.

The programmes of support/development for agriculture and rural areas have been generally launched since 2005 and they encouraged transformations in agriculture as a result of the cessation of the agricultural activity by persons of pre-retirement age. In this case, of importance was support in a form of early retirement for those who had not yet reached the statutory retirement age. Concurrently, administrative measures have been proposed to support the development of farms managed by young farmers, which constituted an additional incentive for the succession of farms. In connection with the multigenerational model of farm families in Poland, the institutional conditions often resulted in handing over the farm (agricultural land) by the oldest family member to their children, who so far had also managed their own farm (Dudek, 2016). Also, market conditions related to the creation of non-agricultural jobs made farmers of working age take up activity in other sectors of the economy. Wide opportunities to take up competitive non-agricultural employment encouraged a significant part of existing farmers either to retrain or to temporarily suspend their agricultural activity. The reported demand for agricultural land has been translated into purchase or lease transactions.

Table 1. Number, production and economic characteristics of individual farms in Poland

\begin{tabular}{|c|l|r|r|r|r|}
\hline No. & \multicolumn{1}{|c|}{ Specification } & \multicolumn{1}{c|}{2005} & \multicolumn{1}{c|}{2016} & \multicolumn{1}{c|}{$\Delta$} & $\begin{array}{c}\Delta \text { in \%; "-" decrease; } \\
\text { "+" increase }\end{array}$ \\
\hline 1 & Farms number (thousand) & $1,723.9$ & $1,398.1$ & -325.8 & -18.9 \\
2 & Agricultural land (thousand ha) & $13,060.6$ & $13,181.4$ & 120.8 & 0.9 \\
3 & Labour input (thousand AWU) & $2,035.2$ & $1,617.0$ & -418.2 & -20.5 \\
4 & Livestock (thousand LU) & $6,430.3$ & $5,923.5$ & -506.8 & -7.9 \\
5 & Farms with livestock (thousand) & $1,247.6$ & 712.6 & -535.0 & -42.9 \\
6 & Standard output (million EUR ) & $20,824.1$ & $21,824.3$ & 1000.2 & 4.8 \\
7 & Standard gross margin (thousand ESU) & $9,963.9$ & $9,283.4$ & -680.5 & -6.8 \\
\hline
\end{tabular}
Agricultural land cultivated according to GAEC requirements.
Arce: Prepared on the basis of FSS 2005 and 2016 data.


The area of utilised agricultural land in good agricultural condition was more than 13 million ha. Taking into account the percentage changes, it can be considered that this area has not changed over the analysed years. However, the area of agricultural land in absolute terms increased by 121 thousand ha, which was the result of the introduced commitments relating to the receipt of direct payments by maintaining land in good agricultural condition. Before Poland accession to the EU, this land was not used and was partially set aside. The legal obligation to restore land use or to maintain it in a form of fallow land (i.e. land maintained in good agricultural condition) has been translated into the environmental-oriented agricultural practices of their users. Farmers interested in receiving direct payments were required to follow certain agricultural practices on agricultural land used.

At the same time, human labour inputs in agriculture have been significantly reduced, by $1 / 5$. These changes resulted from transformations in agriculture, as a result of a reduction in the number of farms and an increase in the average farm area, which made it possible to reduce the labour inputs and supported their effective use. Another important factor was the changing agricultural production technology, resulting from modernisation of farms. The observed substitution of human labour on farms for objectified labour (costly investments or changes in the agricultural production technology by simplification, automation and mechanisation of this process) stemmed, to a significant extent, from support for agriculture under rural development programmes covering co-financing of costly investments (including improvements in equipment of building and the purchase of agricultural equipment).

During the analysed period, many farms resigned from the livestock production - the number of farms with animals decreased by $43 \%$ in Poland. The livestock production is a section of agricultural production that requires significant labour inputs and a large involvement of the farmer in daily on-farm duties. The outflow of labour force from agriculture and the transformation of farms related to the simplification of agricultural production contributed to the resignation from the labour-intensive livestock production. This process has had a negative environmental impact, due to a reduction in the amount of natural fertilisers of animal origin and the progressive dependence of the agricultural production on industrial means of agricultural production (mineral and chemical fertilisers). The measurable effect of reducing the amount of natural fertilisers in non-livestock farms is also a change in the balance of soil organic matter, which may be reduced partly by reorganising the agricultural production towards increasing the structure-forming crops or purchasing these fertilisers from producers involved in the large-scale livestock production. In general, the livestock population in Poland decreased by $8 \%$. This decrease mainly affected farms with the low animal population, which resigned from the livestock production.

The measurable determinant of the economic potential of farms is the standard output and standard gross margin. In the case of the standard output, an increase of nearly $5 \%$ has been reported in the analysed years while the standard gross margin decreased by $7 \%$. Discrepancies between these categories result from a significant impact on the direct costs of the agricultural activity. The increase in the direct costs in the analysed period was not reduced by proportional changes in the value of the agricultural production. This 
increase was particularly related to the prices of industrial means of agricultural production, including mineral fertilisers, plant protection products, animal feedstuffs and feed additives. In addition, in the analysed period the dependence of the agricultural production on external (industrial) means of production increased, as a consequence of the more and more common separation between the crop production and livestock production on farms.

In the analysed period, there were significant changes in the production and economic structure of farms (Fig. 1). Taking into account the area of agricultural land used on the farm, the share of the smallest farms with an area of 1-5 ha decreased, while it substantially increased in the case of medium and large farms with an area of 25 ha, particularly those with an area of 50 ha. These values confirm the thesis of the progressive land concentration process in large and very large farms, which gradually increase their production potential.

The structure of the economic potential of farms has also changed significantly. Similar trends appeared in the case of the distribution of farms by standard output and standard gross margin. The share of the smallest farms (those producing less than EUR 8,000, as well as generating the standard gross margin of up to 4 ESU) increased, which indirectly indicates to the fact that farms with the lowest economic potential resign from the agricultural production. At the same time, the share of medium farms decreased in favour of large farms. The biggest changes applied to very large farms, which accounted for only $1 \%$ of the farms population (2005), although their share increased to more than $2 \%$ (2016). The presented farm structures point to an increase in farms with the greater production and economic potential.

a) Agricultural land in ha/farm

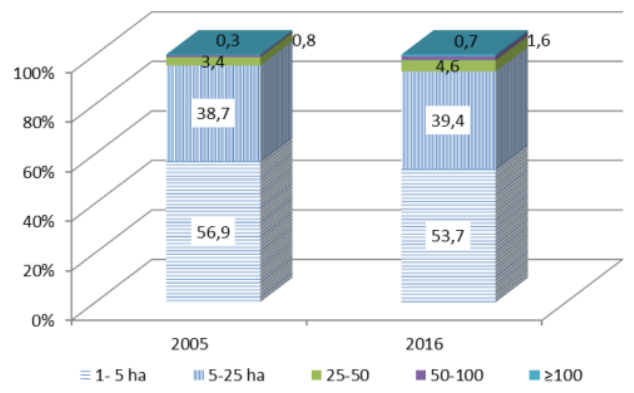

b) Standard output in thousand $€ /$ farm

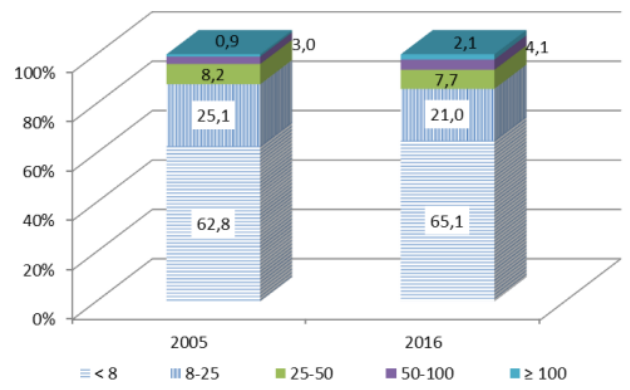

Figure 1. Farms'structure according to production (a) and economic potential (b)Source: Prepared on the basis of FSS 2005 and 2016 data.

Changes in individual agriculture are translated into the features of the average farm. As indicated in Table 2, the average individual farm is small, both in terms of the area used for agricultural purposes and of the generated standard agricultural output. Nevertheless, in the analysed period, the average farm significantly increased its area - by around $1 / 4$, which resulted in an improvement in their economic potential - almost by $30 \%$ in the case of the standard output and $14 \%$ in the case of the standard gross margin, while maintaining the comparable labour inputs. Having regard to the area of the average farm, the input intensity of human labour has decreased significantly in the analysed years, 
both per unit area and per standard output and margin.

On the one hand, in the analysed period, a decrease in the animal population and the number of livestock farms was observed while on the other, there was a concentration of the animal population in some of them. Farms specializing in the livestock production increased its scale (animal population increased by $60 \%$ ). These figures, on the one hand, confirm the progressive process of specialization of farms oriented towards the livestock production and, on the other, point to the growing population of non-livestock farms in which the livestock production was not the dominant production activity in the previous years. The changes presented in individual agriculture are an important background for assessing the economic sustainability of farms in the analysed period of several years.

Table 2. Production and economic potential of an average individual farm in Poland

\begin{tabular}{|r|l|r|r|r|}
\hline No. & \multicolumn{1}{|c|}{ Specification } & \multicolumn{2}{|c|}{2005} & \multicolumn{2}{c|}{2016} & $\begin{array}{c}\Delta \text { in \%; "-" decrease; } \\
\text { "+" increase }\end{array}$ \\
\hline 1 & Agricultural land (ha) & 7.6 & 9.4 & 23.7 \\
2 & Labour input (AWU) & 1.18 & 1.16 & -1.69 \\
3 & Livestock (LU) & 5.2 & 8.3 & 59.6 \\
4 & Standard output (EUR thousand) & 12.1 & 15.6 & 28.9 \\
5 & Standard gross margin (ESU) & 5.8 & 6.6 & 13.8 \\
\hline
\end{tabular}

* Average livestock number in livestock farms.

Source: Prepared on the basis of FSS 2005 and 2016 data.

\subsection{Farms`Economic Sustainability}

Table 3 shows the values of basic indicators that can be used to assess farms economic sustainability. These values indicate some improvement in farms 'economic sustainability in the analysed period, that concerned land productivity and labour economic efficiency, as well as symptoms of changes in the farms` local activity. A slight weakening in market activity and targeting farm on agricultural activity as the main source of household income was observed simultaneously.

In the context of ensuring food security particularly important is the increase in land productivity. The average land productivity (standard output per hectare of agricultural land) was 1.7 thousand EUR/ha (2016), that increased about 4\% in the analysed period. This increase can be consider rather small, although it takes place in the desired direction. In this context, decrease in livestock production in the period played the important role, that affected the total value of agricultural production.

The biggest positive changes were recorded in the potential labour charges. The standard gross margin per labour unit was used as a measure of the economic efficiency of labour and capacity of the farm to income generation. The data showed that the value of standard gross margin in an average farm was less than 5.8 ESU/AWU in 2016 and increased more than $17 \%$ in the analysed period. Significant progress of potential labour charges was not only the effect of standard gross margin improvement, but also (or even mostly) significant labour input decrease, as the effect of farm reorganization towards agricultural production simplification and specialization.

Local farms `activity is particularly important in the context of rural vitality and generally economic sustainability. This group of local market farms is of particular importance for 
the local food system and indirectly for socio-economic development of local communities. In Poland, the role was played by $18 \%$ of farms (2016) and there was observed small positive change between 2005-2016.

Market activity of farms is evidenced also by percentage of market agricultural holdings. In the context of ensuring a sufficient supply of agri-food products, special importance is given to market holdings, i.e. those which sell at least the half of agricultural production volume. They are complemented by subsistence holdings, which produce mainly for own needs of households. More than two thirds of Polish farms are market holdings (2016) a significant and numerous group. Between 2005 and 2016 the share decreased less than 3 p.p. The tendency maintenance wouldn 't be beneficial for society generally, including farmers `economic situation.

The last indicator of economic sustainability is the percentage of farmers' holdings - or more precisely - the share of households with a farm's owner and predominant agricultural income. About 37\% of farms is classified into this group (2016). The share of farmers' holdings slightly decreased in analysed period - about 3 p.p. These results indicated a relatively more frequent orientation of farms on non-agricultural sources of household income. Other sources of household income probably may gain in importance due to e.g. the changeable profitability of agricultural production, significant investment and a high debt level, and thus the need to secure liquidity in the form of non-agricultural income. In 2016, 82\% of farms derived non-agricultural income (Fig. 2) and this parentage was higher about 6 p.p. in comparison with 2005. These figures indicated a progressive diversification of households' incomes. In 2016, more households gained income from non-agricultural activity, as well as contract work and other sources, simultaneously less from pensions.

In the case of households with non-agricultural activity, additional income sources are generated based on the farms' resources and assets (labour, land, buildings, machinery, etc.). This integration of non-agricultural activities, which supplemented agricultural activities, influenced the efficient use of agricultural holdings' resources. Farmers carry out gainful non-agricultural activity related directly to the farm (own production activities or services). While contract work is particularly advantageous form for holdings with own/family labour surplus. Traditional Polish farms are multi-generational households that justify high percentage of households gaining income from pensions. The lastmentioned category is income from other non-wage sources. This category is quite broad and includes e.g. social assistance, scholarships, revenue from capital deposits, lease of land or income obtained by the family member from foreign work.

Farm Structure Survey data indicated the changing socio-economic farms types, that were the result of dominating income source. In 2005, farmers agricultural holdings dominated in the socio-economic farms 'structure, while in 2016, the share of this group was comparable to employees ' households. Also a higher percentage was reported in the case of entrepreneurs ' households and others in 2016, while opposite tendency was observed in the case of pensioners households. The differences in these structures indicated a change in the typology of agricultural holdings, which due to various considerations, including market, institutional and social, farmers are diversifying their sources of income, and, increasingly, non-farm sources of income become the dominant in the income of the household. 
Table 3. Changes in farms`economic sustainability

\begin{tabular}{|c|l|r|r|r|}
\hline No. & \multicolumn{1}{|c|}{ Specification } & \multicolumn{1}{|c|}{2005} & \multicolumn{1}{c|}{2016} & \multicolumn{1}{c|}{$\Delta$ in \% or p.p. } \\
\hline 1 & Standard output (thousand EUR/ha) & 1.59 & 1.66 & 4.40 \\
2 & Standard gross margin (ESU/AWU) & 4.90 & 5.74 & 17.14 \\
3 & Local market farms (\%) & 16.23 & 17.50 & 1.27 p.p. \\
4 & Market farms (\%) & 69.43 & 66.86 & -2.57 p.p. \\
5 & Farmers` holdings (\%) & 40.43 & 37.47 & -2.96 p.p. \\
\hline
\end{tabular}

*p.p. - percentage points.

Source: Prepared on the basis of FSS 2005 and 2016 data.

a) Structure of holdings

by the socio-economic type

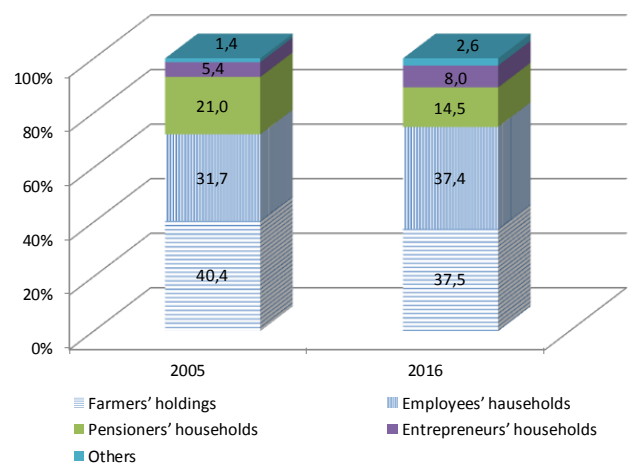

b) Farms by non-agricultural income sources $(\%)$

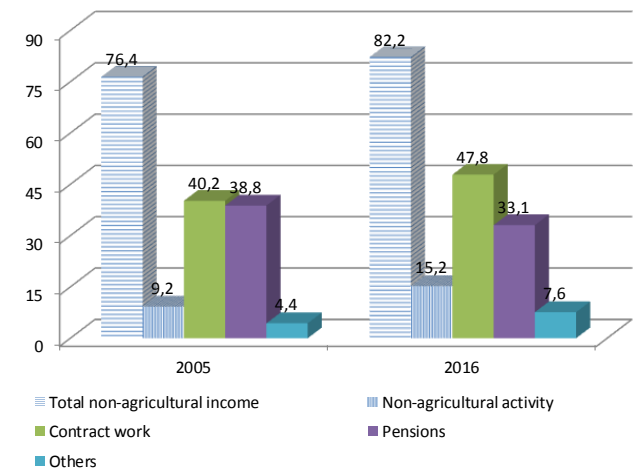

Figure 2. Sources of farms' incomes

Source: Prepared on the basis of FSS 2005 and 2016 data.

\section{Conclusions}

The article presented the proposal for measuring economic sustainability of farms in Poland using the data of the Farm Structure Survey 2005 and 2016. The analysis included individual farms with an area of at least 1 ha of agricultural land. This article adopted the following indicators of economic sustainability: land productivity, labour profitability, market orientation of farms and sources of households' income and maintenance. There was indicated the direction of farms 'development in Poland in the context of economic sustainability.

Based on the research, the main conclusions are as follow:

- Statistical data collected under Farm Survey Structure 2005 and 2016, that are in possession of national statistical offices (in the EU members) and EUROSTAT, allow the multifaceted assessment of farms ' economic sustainability, that takes into account both the production factor effectiveness in agriculture and farms `market activity.

- Between 2005-2016 there were observed significant changes in individual agriculture in Poland, which concerned farms ` number and labour inputs reduction, the increase of an average farm`s production and economic potential, as well as simplification of agricultural production at the farm level. Institutional considerations connected with Poland accession to the EU were an important factor in this case. 
- Farms in Poland develop in two directions, some of them are in the process of agricultural production simplification (significant increase in population of farms without livestock), while others raise their level of specialization in animal production. Compared two ways potentially bring environmental costs and organizational challenges at the farm level.

- Farms economic sustainability in Poland partly enhanced, which essentially followed indicators of economic efficiency improvement, that are important to food security and labour charges. While, there were observed symptoms of worsening economic sustainability in terms of farms ` market activity - decrease of the scale of farms `linkages with market, as well as the percentage of farms oriented on agricultural activity.

- The structure of households` income sources changed significantly during the period. The importance of non-agricultural incomes increased. The causes of this processes can be found in different conditions, namely: institutional (encouraging farmers to entrepreneurship), market (the variability of agriculture effectiveness), as well as social (multigenerational model of farming family).

- The accession of Poland to the EU has helped to improve the economic situation in agriculture as a result of the implementation of rural development programmes, covering both instruments aimed at improving the efficiency of agricultural activity, and the development of non-agricultural activities in rural areas.

\section{References}

Commission of the European Communities (CEC). (2000). Indicators for the Integration of Environmental Concerns into the Common Agricultural Policy. Communications from the Commission to the Council and the European Parliament. COM(2000). Brussels.

Dudek, M. (2016). Sukcesja indywidualnych gospodarstw rolnych jako czynnik przeobrażeń strukturalnych w polskim rolnictwie. Studia i Monografie. No. 170, IERiGŻ-PIB, Warszawa.

European Comission (EC), Schaefer, F., Luksch, U., Steinbach, N., Cabeca, J., Hanauer J. (2006). Ecological Footprint and Biodiversity. Luxemburg.

European Comission (EC). (2008). Streamlining of environmental indicators, project summary. Task force on the ESEA meeting of 9-10 April 2008, Eurostat.

Faber, A. (2007), Przeglad wskaźników rolnośrodowiskowych zalecanych do stosowana w ocenie zrównoważonego gospodarowania $w$ rolnictwie. IN: A. Harasim (ed.), Sprawdzenie przydatności wskaźników do oceny zrównoważonego gospodarowania zasobami środowiska rolniczego w wybranych gospodarstwach, gminach $i$ województwach. Studia i Raporty IUNG-PIB, No. 5, Puławy.

Goraj, L., Bocian, M., Cholewa, I., Nachtman, G., Tarasiuk, R. (2012). Wspótcaynniki Standardowej Produkcji „2007” dla celów Wspólnotowej Typologii Gospodarstw Rolnych. Warszawa.

Huylenbroeck, G. van, Durand, G. (eds.). (2003). Multifunctional Agriculture. A New Paradigm for European Agriculture and Rural Development, Ashgate, Hampshire-Burlington.

Jankowiak, J., Bieńkowski, J. (2007). Syntetyczna ocena zrównoważonego rozwoju gospodarstw rolnych. Fragmenta Agronomia. Vol. 3, No. 95, pp. 192-2004. Pulawy

Loon, G. W. van, Patil, S. G., Hugar, L. B. (2005), Agricultural Sustainability. Strategies for Assessment. SAGE Publications, New Delhi/Thousand Oaks/London.

Majewski, E. (2008). Trwaly rozwój i trwałe rolnictwo - teoria a praktyka gospodarstw rolniczych. SGGW. Warszawa.

Ministry of Agriculture and Rural Development. (2018). Wsparcie Rolnictwa, http://www.minrol.gov.pl/Wsparcie-rolnictwa, access on: 20.04.2018.

OECD. (1999). Environmental indicators for agriculture: Issues and design. Proceeding of the York Workshop. Vol. 2. Paris.

OECD. (2001). Environmental indicators for agriculture: Methods and results. Executive Summary. Vol. 3. Paris. 
Pretty, J. (2008). Agricultural Sustainability: Concepts, Principles and Evidence. Philosophical Transactions of the Royal Society B. No. 363. pp. 447-465, rstb.royalsocietypublishing.org.

Sadowski, A. (2012). Zrównoważony rozwój gospodarstw rolnych z unvalędnieniem wplywu wspólnej polityki rolnej Unii Europejskiej. Rozprawy Naukowe No. 447. Uniwersytet Przyrodniczy. Poznań.

The Royal Society. (2009). Reaping the Benefits: Science and the Sustainable Intensification of Global Agriculture. London.

Toczyński, T., Wrzaszcz, W., Zegar, J.St. (2009) Z badań nad rolnictwem społecznie zrómnoważonym (8). Zrównoważenie polskiego rolnictwa w swietle danych statystyki publicznej. IERiGŻ-PIB. No. 161. Warszawa.

Toczyński, T. Wrzaszcz, W., Zegar J.St. (2013). Zrównoważenie polskiego rolnictwa. Powszechny Spis Rolny 2010. GUS. Warszawa.

Wilk, W. (2005). Koncepcja wykeorysstania danych rachunkowych FADN do ustalenia stopnia zrównoważenia gospodarstw rolnych. IN: J.St. Zegar (ed.), Koncepija badañ nad rolnictwem spotecz̨nie zrónnoważonym. IERiGŻ-PIB. pp. 134-152. Warszawa.

World Commission on Environment and Development. (1987). Our Common Future. The World Commission on Environment and Development, Oxford University Press, 1987.

Woś, A., Zegar, J.St. (2002). Rolnictwo spotecznie zrónnoważone. IERiGŻ. Warszawa.

Wrzaszcz, W. (2014). Sustainability of Agricultural Holdings in Poland. IERiGŻ-PIB. Studia i Monografie. No. 161. Warszawa.

Wrzaszcz, W., Zegar, J.St. (2014). Economic sustainability of Farms in Poland. European Journal of Sustainable Development, 3, 3, 165-176.

Zegar, J.St. (2012). Wspótczesne wyzwania rolnictwa, WN PWN. Warszawa.

Zegar, J. St., Wrzaszcz, W. (2017). The Holism Principle in Agriculture Sustainable Development. Economic and Environmental Studies. Vol. 17. No. 4 (44/2017), 1051-1069. 